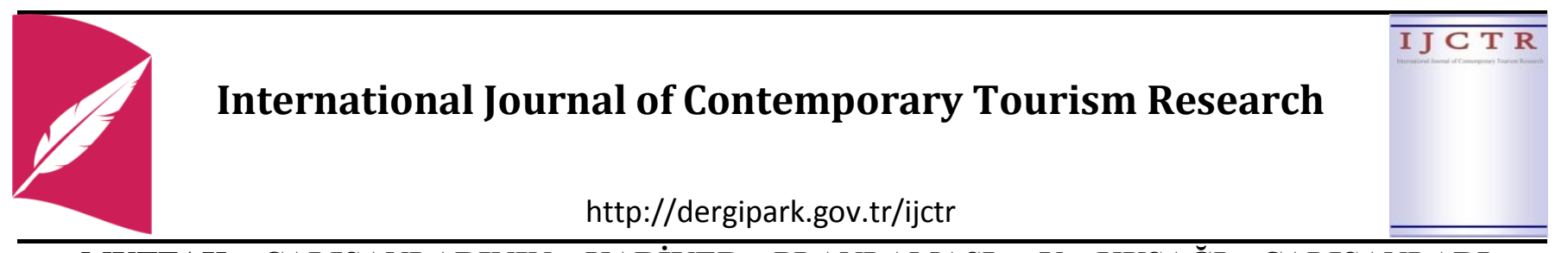

MUTFAK ÇALIŞANLARININ KARİYER PLANLAMASI:
ÜZERINE BİR ARAŞTIRMA

Burçin Cevdet ÇETINSSÖZ1 ${ }^{1}$ Eda HAZARHUN², Okan GÜNDOĞDU ${ }^{3}$

ÖZET

Bu çalışmada y kuşağı mutfak çalışanlarının kariyer planlamaları ve beklentilerinin ortaya konması amaçlanmıştır. Bu kapsamda araştırma evreni olarak İstanbul'da bulunan 8 beş yıldızlı otel işletmesinde çalışan y kuşağı mutfak çalışanlarına kolayda örneklem yöntemi ile anket uygulanmış ve toplamda 250 çalışandan veri toplanmıştır. Y kuşağ mutfak çalışanlarından anket yöntemi ile toplanan veriler bağımsız çift örneklem T-testi, tek yönlü varyans analizi (Anova), Post-Hoc ve Açımlayıcı Faktör Analizi uygulanmıştır. Açımlayacı faktör analizi sonucuna göre kariyer planlaması kariyer algısı ve kariyer değişimi olarak iki temel boyut altında toplanmıştır. Ayrıca y kuşağı mutfak çalışanlarının medeni durumuna göre kariyer algıları arasında anlamlı bir farklılık belirlenirken kariyer değişimleri arasında herhangi bir farklılık belirlenememiştir.

Anahtar Kelimeler: Kariyer Planlama, Kariyer Değişimi, Mutfak Çalışanları, Y Kuşağl

Jel Sinıflama Kodları: M12, Z31

\title{
CAREER PLANNING OF KITCHEN EMPLOYEES: A STUDY ON GENERATION Y CULINARY EMPLOYEES \\ Research Article
}

\begin{abstract}
This study aims to determine career planning and expectations of kitchen employees from generation Y. In this regard, a survey has been conducted to 250 kitchen employees from generation $\mathrm{Y}$ working in eight hotels with five stars located in Istanbul Province. The survey has been conducted with convenience sampling method. Data collected from 250 generation Y culinary employees has been analyzed with Independent Samples T-Test, One Way Analysis of Variance (anova), Post-Hoc, and Exploratory Factor Analysis. According to the results of exploratory factor analysis career planning consists of two main dimensions as "career perception" and "career change". In addition, according to marital status generation $\mathrm{Y}$ culinary employees, there is significant difference in regards to career perception whereas there is no significant difference in regards to career change.
\end{abstract}

Key Words: Career Planning, Career Change, Kitchen Employees, Generation Y

JEL Classification Code: M12, Z31

\footnotetext{
${ }^{1}$ Doç.Dr., Mersin Üniversitesi, Anamur Meslek Yüksekokulu, Seyahat Turizm ve Eğlence Bölümü, cetınsoz@yahoo.com, orcid.org/0000-0003-1703-8067

2 Doktora Öğrencisi, Dokuz Eylül Üniversitesi, Sosyal Bilimler Enstitüsü, Turizm İşletmeciliği Anabilim Dalı, edahazarhun@gmail.com, orcid.org/0000-0003-4798-1857

${ }^{3}$ Yüksek Lisans Öğrencisi, Mersin Üniversitesi, Sosyal Bilimler Enstitüsü, Gastronomi ve Mutfak Sanatları Anabilim Dalı., salim.okan.gundogdu@gmail.com, orcid.org/0000-0003-4514-975
}

“Çetinsöz B. C., Hazarhun E. ve Gündoğdu O. (2020). Mutfak Çalışanlarının Kariyer Planlaması: Y Kuşağı Çalışanları Üzerine Bir Araştırma, International Journal of Contemporary Tourism Research, Vol 4: No: 1, p. 15-30, doi: 10.30625/ijctr.643857" 


\section{GíRis}

Günümüzde küreselleşme ve teknolojik gelişmeler iş yaşamına birçok yenilik getirmiş ve çalışanlar arasında rekabet ortamını arttırmıștır (Ahmetoğulları ve Güneş, 2017). Bu rekabet ortamında çalışanların iş yaşamlarında kalıcılığını sürdürmeleri, kişisel gelişimlerini sağlamalarına bağlıdır (Temeloğlu ve Aksu, 2016).Çalışanların kişisel gelişimlerini sağlaması, kariyer planlamalarını gerçekleştirmeleri ile mümkün olacaktır (Taşlıyan, Arı ve Duzman, 2011). İş yaşamında bireylerin seçtiği kariyer, tüm iş yaşamlarını etkilemektedir. Bundan dolayı çalışanlar kariyer planlamalarını gerçekleștirirken kendi özel yeteneklerinin farkına varmalı, zayıf ve üstün yönlerini belirlemeli ve bu doğrultuda kariyer planlarına yön vermelidirler (Ergün, 2007).

Turizm sektörü de, otel işletmeleri, restoranlar, seyahat acenteleri, hediyelik eşya dükkânları, tur operatörleri ve eğlence hizmetleri başta olmak üzere çok sayıda kuruluşu kapsadığından turizm eğitimine sahip bireyler için çeșitli kariyer imkânları sunmaktadır (Temeloğlu ve Aksu, 2016; Eren, 2019). Özelikle de turizm sektöründe son yıllarda aşçılık mesleğine karşı ilgi artmış ve asçıllık saygın mesleklerden biri olarak kabul görmeye başlamıştır (Prattern, 2003b). Bu sayede aşçılık mesleğinin, turizm endüstrisinde göz kamaştıran ve prestijli bir meslek konumuna gelmesi son yıllarda genç kuşağ 1 da otel ve restoran mutfaklarında çalışmaya cesaretlendirmiştir (Pratten, 2003a). Bu mutfaklarda çalışan gençlerde farklı kariyer planlarına sahiptir (Kusluvan ve Kusluvan, 2000). Çünkü kariyer planlamaları, iș dünyasında çalışan kișilerin kuşaklarına göre farklılık göstermektedir (Altuntuğ, 2012; Akdemir ve diğerleri, 2013;Metin ve Kızıldağ, 2017; Akgemci ve Kalfaoğlu, 2018). Göktaş (2017)' da iş yerlerinde çalışan x,y, z ve patlama kuşağı üyelerinin farkl1 kariyer yaklaşımları benimsediklerine vurgu yapmıştır. $\mathrm{Bu}$ kuşak üyelerinin kariyer beklentilerini ve hedeflerinin ortaya konması iş hayatında yöneticilerin yönetim planlarını kolaylaştıracaktır (Zvikaite- Rotting, 2007). Bu kapsamda y kuşağ 1 mutfak çalışanlarının kariyer planları ve süreçlerinin ortaya konması hem işletmelerde görev yapan yöneticilerin yönetim planlarının belirlenmesi hem de gastronomi ve turizm eğitimi alan öğrencilerinin kariyer hedefleri açısından yol gösterici olacaktır (Eren, 2019). Ayrıca alanyazında bayan aşçıların deneyimleri (Haddaji, Albors-Garrigos ve Garcia- Segovia, 2017), iyi bir şef nasıl olması gerektiği (Prattern, 2003b), aşçıların karşılaştıkları zorluklar (Zopiatis, Kyprianou ve Pavlou, 2014), şeflerin eğitimleri ve meslekte kalmalarının sağlanması (Pratten, 2003a), aşçılık programında okuyan öğrencilerin mesleki tutumlar1 (Harbalığlu ve Ünal, 2014) ve gastronomi ve mutfak sanatları bölümü lisans öğrencilerinin sektöre yönelik algılarının kariyer yapma niyetlerine etkisi (Özdemir ve Önçel, 2019), şef adaylarının niteliklerine ilişkin mutfak şeflerinin görüşleri (Yılmaz, Erdem ve Arman, 2018) konulu çalışmalar gerçekleştirilmesine rağmen y kuşağı mutfak çalışanlarının kariyer planlaması ile ilgili bir çalışmaya henüz rastlanılmamıştır. Otel ve restoran işletmelerinin başarıya ulaşmasında mutfak çalışanlarının kilit rol oynamasından dolayı y kuşağı mutfak aşçılarının kariyer planlamaları hakkında detaylı bir çalışmanın gerçekleştirilmesi işletmeler için faydalı olacaktır. $\mathrm{Bu}$ nedenle bu çalışmada $\mathrm{y}$ kuşağı mutfak çalışanlarının kariyer planları ve beklentilerinin ortaya konması amaçlanmıştır.

\section{LITERATÜR TARAMASI}

\section{Y Kuşağı}

Y kuşağ1 1980 ile 2000 arasında dünya'ya gelen nesile verilen addır (Akdemir ve diğerleri, 2013). Sheahan (2009)'a göre y kuşağı internet kuşağ 1 olarak da adlandirılmakta ve 1978 -1994 yılları arasında dünyaya gelen kişileri kapsamaktadır. Fox (2011)'e göre ise y kuşağı 1981 ve 1995 y1lları arasında meydana gelen kişilerden oluşmaktadır. $\mathrm{Bu}$ kuşak üyeleri, dünya genelinde Google, MSN, akıllı telefonlar ve dijital kameraların yaygınlaştığı (Reeves ve Oh, 2008;Türk, 2013) savaş ve kıtlık dönemlerinin yaşanmadığı, teknolojinin geliştiği, ülkelerin refah ve zenginlik seviyelerinin arttı̆̆ dönemde yaşamaktadırlar (Bekmezci, 2017).

Son yıllarda dünya nüfusun \% 35'i y kuşağ1 üyelerinden oluşmaktadır (Konakay, 2018). Bu rakamın 2025 yılında $\% \quad 60$ ulaş1lacağ 1 ön görülmektedir (Deloitte, 2017). Bundan dolay1 y kuşağ1 üyelerinin kişisel özeliklerinin bilinmesi iş yaşamında bireysel ve örgütsel bazda başarının gelişmesinde önem teşkil etmektedir (Konakay, 2018). Y kuşağının öne çıkan en temel bireysel özelliği, teknolojiyi yaşamlarının her alanlarında etkin kullanmalarıdır (Tyler, 2007). 
Günümüzde iş hayatına y kuşağı hızlı bir giriş yapmış ve bu kuşak üyeleri iş hayatında yönetici pozisyonlarında çalışmaya başlamıştırlar. Y kuşağı üyelerinin genel özeliklerini sabırsız, öz güvenli, bağımsızlığına düşkün, araştırmacı ve sorgulayıcı yönleri yüksek, sosyal medyayı aktif bir şekilde kullanan, girişimcilik ruhu fazla, aile ve arkadaşlarına düşkün ve kariyerlerinde iş yaşam dengesini iyi ayarlayanlar olarak siralamak mümkündür. Ayrıca y kuşağı üyelerinin kariyer değişim hızları diğer kuşaklara kıyasla daha yüksektir (Acılıŏ̆lu, 2015). Y kuşağı iş yaşamında kariyer gelişimine (Brown, 2013) ve bireysel kariyer planlamasına önem vermektedirler (Koç, Öztürk ve Yıldırım, 2016).

\section{Mutfak Çalışanlarının Kariyer Planlaması}

Kariyer, 'bir bireyin iş hayatındaki geçmişini anlatmak' olarak tanımlanmaktadır. Alanyazında farklı kariyer tanımları gerçekleştirilmiştir. Wang ve Tsai (2012)'e göre kariyer, iș hayatında bulunan bireylerin, iş hayatları süresince gelişim gösterdiği evrelerin dizisi olarak tanımlanmıştır. Eren (2019), kariyeri, çalışanların işe başladığı süre zarfından başlayarak, mevcut işine kadar geçen süreçte hangi görevlerde yer aldığını gösteren bir kavram olarak tanımlamıştır. Can, Kavuncubaşı ve Yıldırım (2009)'a göre de kariyer, çalışanların iş yaşamlarında en başarılı süreçlerini geçirdiği ve yaşamlarının büyük bir kısmını harcadığı meslek ve iş sahalarıdır.

Çalışanların ve örgütlerin iş yaşamında başarıları üzerinde kariyer planlamasının önemi büyüktür. Kariyer planlaması, bireylerin iş yaşamlarında üstün ve zayıf yönlerini belirleyerek, kendi yetenekleri doğrultusunda iş hayatında kariyer amaçlarına erişmek için kişisel eğitim ve gelişim programlarının ayarlaması olarak tanımlanmakta (Kocabey, 2010) ve bireysel ve örgütsel kariyer planlaması olarak iki unsura ayrılmaktadır (Ertürk, 2011). Bu çerçevede bireysel kariyer planlaması, iş yaşamında çalışanların kendi üstün ve zayıf yönlerini tespit ederek kariyerlerinde başarıya ulaşacak yolları farkına varmaları olarak tanımlanmaktadır (Acar ve Özdaşl1, 2017).

İş yaşamında bireysel kariyer planlaması dışında örgütsel kariyer planlaması da örgüt ve çalışanların başarısında önemli rol oynamaktadır (Yaprak, Hotamışlı ve Gerek, 2010). Örgütsel kariyer planlaması, işletmelerin amaçlarına göre ihtiyaç duydukları çalışan sayısının tahmin edilmesi ve bu çalışanların iş yaşamında kariyerlerini geliştirmesi için iç ve dış kaynakların belirlenerek çalışanlara sunulması süreçlerini kapsamaktadır (Dessler, 2013). İşletmelerde kariyer planlama süreci öz değerlendirme, araştırma, deneyim, karar verme ve uygulama aşamaları olmak üzere beş aşamayı kapsamaktadır. Aşağıda bu aşamalar ayrıntılı olarak ele alınmaktadır (Öztemel, 2019).

- Öz Değerlendirme: Birey, öz değerlendirme aşamasında kendisinin ilgi alanları, kişisel özellikleri, beceri ve yeteneklerini değerlendirir. $\mathrm{Bu}$ değerlendirme aşamasında birey kendi yeteneklerinin farkına varır. $\mathrm{Bu}$ yetenekler ile seçmeyi düşündüğü mesleğin özelikleri arasında bağlantı kurar. Yani birey kendi kişisel özeliklerine uygun meslek kollarında kariyer planlaması gerçekleştirmeye özen göstermelidir. Örneğin yaratıcılık yeteneği gelişmiş bireyler, oyuncu, mimar, ressam, grafik tasarımcılığı ve müzisyen gibi yaratıcılık gerektiren meslek dallarında başarılı bir kariyere sahip olma şansları daha yüksektir (Ünsal, 2014).

- Araştırma: Bireyler kendi öz yeteneklerini değerlendirdikten sonra kariyer yapmay1 düşündüğü meslekleri ve çevre koşullarını araştırmaya başlar. Kariyer araştırması hem bireyin kendini hem de çevreyi araştırma sürecini kapsamaktadır. Öz değerlendirme aşamasında kişisel özellikleri, yetenekleri, ilgi alanları ve hobilerini farkina varan bireylerden, araştırma aşamasında değerlendirmelerinin daha genişletmeleri beklenir. $\mathrm{Bu}$ kapsamda aile, arkadaş üyeleri, kariyer danışmanlarından da kişisel yetenekleri hakkında geri bildirim alabilirler. Çevre araştırması ise bireyin seçmeyi düşündügü mesleğin iş tanımları veya başka meslekler, ödüller, çalışma koşulları ve iş grupları hakkında internet, kariyer tanıtım broşürleri ve çalışan bireyler aracılığı ile bilgi toplama sürecini içermektedir.

- Deneyim: Bireyler çevre ve kendi değerlendirmelerini gerçekleştirdikten sonra kariyerlerini gerçekleştirmeyi düşündükleri iş alanları ile ilgili deneyim elde etme sürecine başlamaktadırlar. Deneyimler, staj, yarı ve tam zamanlı ve gönüllü işlerde çalışma ve iş gölgeleme olarakta adlandırılan deneyimli kişilerden izleme olarak kazanılabilir. 
- Karar Verme: Bu aşama bireylerin, karar verme sürecinde yukarıda yer alan üç evrede topladıkları bilgilerin artıları ve eksiklerini değerlendirerek gerçekleştirmek istedikleri kariyer seçenekleri hakkında karar verme sürecini kapsamaktadır. Bireyler, öz değerlendirme ve araştırma sürecinde detaylı ve gerçekçi bir bilgi toplama sürecini gerçekleştirmişler ise karar verme sürecinde elde ettikleri bilgiler arasından kendilerine en uygun olan kariyer seçeneğine yönelme şansları artar.

- Uygulama: Uygulama aşamas1, kariyer seçenekleri hakkında verilen kararın eyleme geçirme sürecini kapsamaktadır. Kısaca bu aşamaya gelen birey kariyer planlamasında nerede olacağından emin olur ve harekete geçer. Örneğin lisansüstü eğitime devam etme kararı alan bir öğrenci bu aşamada farklı üniversitelere lisansüstü eğitim başvurusu yapabilir.

Kariyer planlama süreci hem çevresel hem de kişisel faktörlerden etkilenmektedir. Bireylerin kariyer planlarını etkileyen çevresel faktörler arasında bireylerin aileleri, sosyal geçmişleri ve gelir düzeyleri; bireysel faktörler arasında ise kişisel özelikler, normlar, değerler, inanç ve beklentiler yer almaktadır (Çiftçi, 2011).

Çeşitli meslek grubunda çalışan bireylerin, iş hayatında başarısı üzerinde kariyer planlamasının önemli rolü vardır. Son yıllarda rekabet ortamının arttığ 1 emek yoğun bir sektör olan turizm sektöründe de istihdam edilen bireylerin hem kişisel gelişimlerinin sağlanması hem de işletmelerin hedeflerine ulaşmaları için kariyer planlamasına önem verilmesi gerekmektedir (Perçin ve Çetin, 2016). Özelikle turizm sektöründe çalışmak isteyen gençlerin kariyer planlama süreçleri turizm eğitimini aldıkları eğitim kurumlarında başlamaktadır. Bundan dolayı lise ve üniversitelerde turizm eğitimi gören gençlerin turizm sektörüne yönelik kariyer tutumlarının belirlenmesi önemlidir. Bu kariyer tutumlarının ortaya konması amacı ile alanyazında çeşitli çalışmalar gerçekleştirilmiştir. Örneğin Çavuş ve Kaya (2015), turizm lisans eğitimi alan öğrenciler ile gerçekledikleri çalışmalarında öğrencilerin çoğunluğunun turizm sektöründe kariyerine devam etmek istediklerini ortaya koymuştur. Güzel, Akdağ, Güler ve Şener (2014)'de gerçekleştirdikleri çalışmada öğrencilerin, turizm sektörünün yurt dışında çalışma ve yeni insanlarla tanışma imkânları sağlamasından dolayı turizm kariyerine olumlu baktıklarını belirtmiştirler.Öte yandan Kozak ve Kızılırmak (2001), ön lisans düzeyinde turizm eğitimi alan öğrenciler ile gerçekleştirdikleri çalışmada erkek öğrencilerin otelleri çalışmak için cazip ve turizm sektöründeki işleri saygın olarak görmediği, kız öğrencilerin de turizm sektöründe aile yaşantısını sürdürmenin zor olduğu ifadelerini daha çok tercih ettikleri sonucuna ulaşılmıştır. Ahmetoğluları ve Güneş (2017) tarafından gerçekleştirilen çalışmaya göre de turizm öğrencilerinin cinsiyetlerine göre turizm kariyeri algılarının farklılaştığı belirlenmiştir.

Turizm eğitimi alan öğrencilerin turizm kariyerine karşı tutumları değişiklik göstermesine rağmen son yıllarda turizm sektöründe gençlerin aşçılık mesleğine karşı ilgisi artmakta ve gençler çeşitli motivasyonlar ile mutfak departmanlarında çalışmayı tercih etmektedirler (Kurnaz ve diğerleri, 2014). Örneğin Özdemir ve Önçel (2019) tarafından gerçekleştirilen araştırmaya göre öğrencileri gastronomi alanında kariyer yapmaya yönelten unsurlar arasında, mutfak yöneticilerinin daha alt kademede çalışan personellere yetki vermeleri, öğrencilerin gastronomi alanını sevmeleri, iş motivasyonlarının yüksek olması ve mutfak alanında çalışan personellere toplumun saygı göstermesi yer almaktadır. Harbalıŏglu ve Ünal (2014)'de aşçılık bölümünde okuyan öğrenciler ile gerçekleştirdikleri çalışmalarında, öğrencilerin maddi ve manevi tatmin sağlayacağ mesleklerinde ilerledikçe tecrübelerinin ve işe bağl11ıklarının artacağını düşündükleri için aşçl1ık programını seçtikleri sonucuna ulaşmıştırlar.

Mutfak alanında genç kuşak için farklı kariyer seçenekleri bulunmaktadır. Gençler, mutfak şefi, mutfak şef yardımcısı, kısım şefleri (soğuk mutfak şefi, sicak mutfak şefi, garnitürcü şefi, pastane şefi), kısım aşçıları (mezeci, kasap, 1zgaracı, balıkçı, çorba aşçısı, sebze aşçısı, pastacı, dondurmac1, ekmekçi, personel aşçısı ve izin doldurucu aşçı) ve kısım aşçı yardımcısı olabilir (Y1lmaz, Y1lmaz, Yilmaz, 2013). Mutfak aşçılarının kariyerlerini geliştirmek için staj eğitimi almas1, mutfak malzemelerinin kullanımını, pişirme işlemlerini ve güvenlikle ilgili bilgileri bilmesi ve müşterilerin sürekli değişen lezzet taleplerini karşılamaları gerekmektedir (Pratten, 
2003b). Diğer bir taraftan mutfak çalışanlarının kariyer planlarında hem pratik hem teorik dersler önemli yer tutmaktadır. Öncelikle aşçı adaylarına sinıf ortaminda teorik dersler verilmekte ve daha sonra teorik dersler uygulama mutfaklarında pratiğe dönüştürülmektedir. Ayrıca uygulama mutfaklarında her aşçı adayının uygulama yapması, el becerilerinin gelişimini sağladığı için kariyerlerine olumlu katkı sağlamaktadır (Öztürk ve Görkem, 2012; Pratten, 2003a).

Aşçılık doğası gereği rekabetçi ve yenilik süreçlerini içeren bir meslek olduğundan aşçıların kendilerini sürekli geliştirmeleri ve zorluklar ile mücadele etmeyi öğrenmeleri gerekmektedir (Manzoori-Stamford, 2013). Bu nedenle özelikle sektöre yeni giren y kuşağ1 aşçıları için kariyer planlaması önemlidir. $\mathrm{Y}$ kuşağı üyeleri kariyerlerinde yeteneklerini ve bilgilerini daha fazla geliştirmek için çalışırlar. Ayrıca Y kuşağı üyeleri kariyer değişikliği içine daha çabuk girebilirler veya sahip olduğu kariyer paralelinde farklı kariyer planlaması gerçekleştirebilirler (Gursoy ve diğerleri, 2008; Acılığlu, 2015). Saxena ve Jain (2012)'de y kuşağı üyelerinin iş yaşamlarında yaklaşık iki yılda bir iş değiştirdiğine vurgu yapmaktadırlar. Örneğin Deloitte tarafindan gerçekleştirilen y kuşağı araştırmasının sonuçlarına göre, Türkiye'de çalışan y kuşağı üyelerinin $\% 46$ 'sı iş yerlerinden iki sene içerisinde ayrılmayı düşünmektedir. $\mathrm{Bu}$ oran dünyada $\% 38^{\prime} \mathrm{e}$ düşmektedir (Deloitte, 2017). Y kuşağı mutfak çalışanlarının da kariyer gelişimleri uzun çalışma saatleri, düşük ücretler, cinsiyetçilik, sosyal yaşama zaman ayırmama gibi problemler yüzünden olumsuz etkilenmekte ve aşçıların bazıları az bir eğitime sahip olarak mesleğin başında bu sorunlardan aşçıllk mesleğini birakmakta veya farklı alanlarda kariyerlerine devam etmektedirler (Pratten, 2003a). Bu sorunlardan dolayı bazı genç mutfak çalışanları aşc1lık mesleğini, okurken, seyahat ederken veya diğer kariyer hedeflerine odaklanırken para kazanmak için yaptıkları geçici bir iş olarak değerlendirmektedirler (Prattern, 2003a).

Araştırmada alanyazından elde verilerden yola çıkarak araştırmanın amacına ulaşılabilmesi için şu araştırma sorusu belirlenmiştir;

Kariyer algısı ve kariyer değişimleri boyutları katılımcıların demografik özelliklerine ve tecrübelerine göre farklılı gösterir mi?

\section{YÖNTEM}

$\mathrm{Bu}$ araştırma y kuşağı mutfak çalışanlarının kariyer planları ve beklentilerini belirlemeyi amaçlamaktadır. Araştırmanın ideal evrenini Türkiye'de 5 yıldızlı otellerin mutfağındaki tüm y kuşağı çalışanları oluşturmaktadır. İdeal evren üzerinde anket uygulaması olanaklı olamadığı için, çalışma evreni tanımlaması yoluna gidilmiştir. Çalışma evreni, genel evrene göre daha somut, araştırmacının gözlem ya da bir şekilde ulaştığı bir örnek kümeden yararlanarak çalışma sonuçlarını genellediği evrendir (Karasar, 2014). Buna göre araştırmanın çalışma evrenini İstanbul'da bulunan 102 adet beş yıldızlı otel işletmesi (İstanbul Kültür ve Turizm Müdürlüğü, 2018) arasında araştırma izni alınabilinen 8 beş yıldızlı otel işletmesinin mutfaklarındaki y kuşağı çalışanları oluşturmaktadır. Araştırmada Aralık 2018-Şubat 2019 ayları arasında "kolayda örnekleme" yöntemi ile yüz yüze görüşülerek toplam 250 çalışanına anket formu uygulanmıştır. Kullanılan anket formu iki aşamadan oluşmaktadır. Birinci bölümde katılımcıların demografik ve mesleki özelliklerini belirlemeye yönelik dokuz soru yer almaktadır. İkinci bölümde, kariyer planlamalarını belirlemeye ilişkin on soru bulunmaktadır. Araştırmada kullanılan kariyer planlaması ölçeği Akdemir ve arkadaşları (2015) ve Ahmetoğlu ve Güneş (2017) güvenilirliği ve geçerliliği teyit edilen çalışmalarından uyarlanmıştır. Kariyer planlaması ölçeği 2 boyut ve 10 ifadeden oluşmaktadır. Araştırmada katılımcıların anket formundaki ifadelere katılım düzeylerini belirlemek amacıyla 5'li likert tipi derecelendirme kullanılmıştır ve puanlama $1=$ Kesinlikle Kat1lmiyorum ve 5=Kesinlikle Katıliyorum olacak şekilde gerçekleştirilmiştir.

Parametrik hipotez testlerinin varsayımlarına göre, verilerin aralıklı ya da oransal olması, verilerin normal dağılıma uyması ve grup varyanslarının eşit olması gerekir (Kalayc1, 2008). Bu araştırmada temel veriler aralıklı ölçekten (5'li tutum ölçeği) elde edilmiştir. Verilerin basıklık ve çarpıklık değerleri -1 ve +1 civarında olduğundan normal dağılıma uymaktadır. Grup varyanslarının eşitliğinde faktörlerin varyanslarının birbirine eşit olduğu görülmektedir. Dolayısıyla bu araştırmada veriler söz konusu özellikleri taşıdığından, parametrik testlere tabi tutulmuştur.

Veri Analiz Yöntemleri 
Anket uygulaması sonucunda elde edilen verilerin istatistiksel analiz tekniklerine geçilmeden önce kategorik sorulara ait betimleyici istatistikler; frekans dağılımları, yüzdelik oranlar, ortalama değerler ve standart sapmalar verilmiştir.

Araştırma sorularındaki farklılık testleri için Bağımsız Çift Örneklem T-testi, Tek Yönlü Varyans Analizi (ANOVA) ve Post-Hoc Analizinden faydalanılmıştır. Ölçeğin güvenilirliği için Cronbach Alpha testi, yapı geçerliliği için ise öncelikle "Açıklayıcı Faktör Analizi" uygulanmıştır.

\section{Güvenilirlik ve Geçerlilik Analizleri}

Ölçme aracının önemli teknik özelliklerinden biri olan güvenirlik, "ölçme aracının ölçtüğü özelliği

Tablo 1: Kariyer Planlaması Ölçeği Güvenilirlik Analizi Bulguları (n=250)

\begin{tabular}{|c|c|c|}
\hline Maddeler & $\begin{array}{l}\text { Düzeltilmiş } \\
\text { Madde } \\
\text { Toplam } \\
\text { Korelasyonu }\end{array}$ & $\begin{array}{c}\text { Madde } \\
\text { Silindiğinde } \\
\text { Cronbach } \\
\text { Alfa Değeri }\end{array}$ \\
\hline $\begin{array}{l}\text { 1.İyi bir otelin mutfağında çalışmam, hem iş yaşamında hem de sosyal } \\
\text { yaşamda prestijli bir kişi olmamda yardımcı olacaktır. }\end{array}$ & .676 & .847 \\
\hline $\begin{array}{l}\text { 2.Kurumsal bir işletmenin mutfağında çalışmam sürekli kariyer } \\
\text { gelişimimin başlangıç noktasıdır. }\end{array}$ & .627 & .851 \\
\hline $\begin{array}{l}\text { 3.Mutfakta bilgi teknolojileri açısından donanımlı olmam, gelecekteki } \\
\text { hedeflerime katkı verecektir. }\end{array}$ & .726 & .844 \\
\hline $\begin{array}{l}\text { 4.Gelecekte mutfakta alanımla ilgili teknik bilgiye ileri düzeyde sahip } \\
\text { olmak istiyorum. }\end{array}$ & .786 & .840 \\
\hline $\begin{array}{l}\text { 5.Mutfakta mütevazı düzeyde gelirle işe başladıktan sonra gelir } \\
\text { düzeyimi çok artırmayı hedeflemekteyim. }\end{array}$ & .656 & .849 \\
\hline 6.Kendi alanımda kendi işimi kurmak istiyorum. & .328 & .875 \\
\hline $\begin{array}{l}\text { 7.Mutfakta herhangi bir kamu dairesinden ziyade özel sektörde } \\
\text { ilerlemek istiyorum. }\end{array}$ & .358 & .872 \\
\hline 8.Alanımda akademik kariyer planlıyorum. & .512 & .861 \\
\hline $\begin{array}{l}\text { 9.Mutfakta nitelikli bir personel olarak işe başlayıp yükselmeyi } \\
\text { hedeflemekteyim. }\end{array}$ & .738 & .842 \\
\hline 10.Yabancı dil öğrenme konusunda hedeflerim var. & .483 & .862 \\
\hline Cronbach Alfa Değeri & \multicolumn{2}{|l|}{0,867} \\
\hline Genel Ortalama & \multicolumn{2}{|l|}{3,883} \\
\hline Hotelling' $\mathbf{T}^{2}$ & \multicolumn{2}{|c|}{$\mathrm{F}_{9 ; 239}=19,585(\mathrm{p} \leq 0,000)$} \\
\hline Toplanamazlık & \multicolumn{2}{|c|}{$\mathrm{F}_{1 ; 9}=4,400 ; \mathrm{p}>0,036$} \\
\hline Sınıflararası R (Tekli ve Ortalama Ölçüm) & \multicolumn{2}{|c|}{$\mathrm{r}=, 373 /, 856(\mathrm{p} \leq 0,000)$} \\
\hline
\end{tabular}

Tablo 1'de kariyer planlamas1 ölçeğini oluşturan ifadelerin genel ortalamas1 3,88 ve ifadeler arasındaki ortalama korelasyon 0,401 olarak ya da özellikleri, ne derecede bir kararlılıkla ölçmekte olduğunun göstergesidir'(Tavşancıl, 2014; Tekin, 2000).Ölçme aracinı oluşturan ifadelerin birbirleriyle tutarlılık gösterip göstermediği, aralarındaki ilişkinin ölçülmesiyle ortaya çıkar. Güvenilirlik katsayısı, 0 ile 1 arasında değerler alır ve bu değerler 1'e yaklaştıkça güvenilirlik artar (Ural ve Kilıç, 2006).

Tablo 1'de güvenilirlik analizinde öncelikle alfa katsayısının kabul edilen güvenilirlik aralığı olan 0,60-0,79 aras1 olmas1, mümkünse 0,80 ve üzeri olup olmadığı (Kalayc1, 2014: 405), ölçek içinde bulunan maddelerin ölçeğin güvenilirliğini bozup bozmadığı incelenmiştir. bulunmuştur. Çoklu korelasyon $\left(\mathrm{R}^{2}\right)$ katsayılarına bakıldığında 6 nolu ifade çoklu korelasyon $\left(R^{2}\right)=0,148$ ve 7 nolu ifade çoklu korelasyon 
$\left(\mathrm{R}^{2}\right)=0,188$ ölçekten çıkartıldığında güvenilirlik katsayısını arttıracaklardır. Ancak 6 nolu ifadenin ölçekten çıkartılması, 7 nolu ifadenin çıkartılması hususunda açımlayıcı faktör analizi sonucunda nihai karar verilecektir. 7 Hotelling $\mathrm{T}^{2}$ testine göre $\mathrm{P}=0,000$ olarak, soru ortalamaları arasındaki farklılığın istatistiksel olarak anlamlı olduğunu ifade etmektedir. Ölçeğin toplanamazlık (nonadditivity) özelliği $\mathrm{p}=0,036$ değeri ile anlaml olduğu belirlenmiştir.
Geçerlilik ise "bir ölçme aracının ölçmeyi amaçladı̆̆ özelliği tam ve doğru olarak, bir başka özellikle karıştırmadan ölçebilme derecesidir" (Tavşancıl, 2014). Yap1 geçerliliği tekniklerinden "açımlayıcı faktör analizi”, araştırmacının ölçme aracının ölçtüğ̈̈ faktörlerin sayısı hakkında bir bilgisinin olmadığ 1 , belli bir hipotezi sınamak yerine, ölçme araciyla ölçülen faktörlerin doğası hakkında bir bilgi edinmeye çalıştığ olarak tanımlanmaktadır (Tavşancıl, 2014).

\section{Tablo 2: Kariyer Planlaması Ölçeği Açımlayıcı Faktör Analizi}

\begin{tabular}{|c|c|c|c|c|c|c|c|c|}
\hline Faktörler & Fak. Yük. & $\begin{array}{l}\text { Öz- } \\
\text { Değer }\end{array}$ & $\begin{array}{l}\text { Açık. } \\
\text { Var.\% }\end{array}$ & $\begin{array}{l}\text { Cronb. } \\
\text { Alpha }\end{array}$ & $\begin{array}{l}\text { Ort. } \\
(\mu 1-5)\end{array}$ & $\begin{array}{l}\text { SS } \\
( \pm)\end{array}$ & $\mathbf{F}$ & $\mathbf{P}$ \\
\hline Kariyer Planlaması & & & 63,602 & ,867 & $3, \mathbf{8 8}$ & 1,06 & & \\
\hline Faktör 1: Kariyer Algısı & & 4,706 & 52,284 & ,849 & 3,82 & 1,09 & 25,702 & .000 \\
\hline $\begin{array}{l}\text { 2.Kurumsal bir işletmenin } \\
\text { mutfağında çalışmam sürekli } \\
\text { kariyer gelişimimin başlangıç } \\
\text { noktasıdır. }\end{array}$ & ,867 & & & & 3,68 & 1,15 & & \\
\hline $\begin{array}{l}\text { 1. İyi bir otelin mutfağında } \\
\text { çalışmam, hem iş yaşamında } \\
\text { hem de sosyal yaşamda prestijli } \\
\text { bir kişi olmamda yardımcı } \\
\text { olacaktır. }\end{array}$ &, 854 & & & & 3,82 & 1,20 & & \\
\hline $\begin{array}{l}\text { 9.Mutfakta nitelikli bir personel } \\
\text { olarak işe başlayıp yükselmeyi } \\
\text { hedeflemekteyim. }\end{array}$ & 675 & & & & 3,99 & 1,10 & & \\
\hline $\begin{array}{l}\text { 3.Mutfakta bilgi teknolojileri } \\
\text { açısından donanımlı olmam, } \\
\text { gelecekteki hedeflerime katk1 } \\
\text { verecektir. }\end{array}$ & ,644 & & & & 4,14 & 1,04 & & \\
\hline $\begin{array}{l}\text { 8.Alanımda akademik kariyer } \\
\text { planlıyorum. }\end{array}$ & ,626 & & & & 3,49 & 1,23 & & \\
\hline Faktör 2: Kariyer Değişimi & & 1,019 & 11,317 & ,721 & 3,99 & 1,04 & 16,249 & .000 \\
\hline $\begin{array}{l}\text { 10.Yabanc1 dil öğrenme } \\
\text { konusunda hedeflerim var. }\end{array}$ &, 787 & & & & 4,11 & 0,99 & & \\
\hline $\begin{array}{l}\text { 5. Mutfakta mütevazı düzeyde } \\
\text { gelirle işe başladıktan sonra } \\
\text { gelir düzeyimi çok artırmayı } \\
\text { hedeflemekteyim. }\end{array}$ & ,649 & & & & 4,01 & 1,03 & & \\
\hline $\begin{array}{l}\text { 7.Mutfakta herhangi bir kamu } \\
\text { dairesinden ziyade özel sektörde } \\
\text { ilerlemek istiyorum. }\end{array}$ & ,640 & & & & 3,68 & 1,10 & & \\
\hline $\begin{array}{l}\text { 4.Gelecekte mutfakta alanımla } \\
\text { ilgili teknik bilgiye ileri düzeyde } \\
\text { sahip olmak istiyorum. }\end{array}$ & ,635 & & & & 4,14 & 1,04 & & \\
\hline
\end{tabular}

Notlar: Varimax Rotasyonlu Temel Bileşenler Faktör Analizi Kaiser-Meyer-Olkin Örneklem Yeterliliğii= ,866. Bartlett's Test of Sphericity: $\mathrm{p}<.000$ (Chi-Square 1126,736 df=36). 
Katılımcıların kariyer planlamasına yönelik açımlayıcı faktör analizi sonucunda iki temel boyut (kariyer algısı ve kariyer değişimi) belirlenmiştir. Kariyer planlaması ölçüm aracında 10 madde bulunmaktadır. Daha anlamlı ve yorumlanabilir bir çözüm elde etmek için, düşük yüklü ya da aynı anda birden fazla faktöre yük veren ifadelerin silinmesi gerekmektedir (Hair, Black, Babin, Anderson ve Tatham, 2006).Bundan dolay1 6 nolu madde (Kendi alanımda kendi işimi kurmak istiyorum) düşük faktör yüküne sahip olmasından dolayı ölçekten silinmiştir. Yapılan faktör analizi sonucunda, ölçeğin açıklanan toplam varyansı 63,602 seviyesinde iken, güvenilirlik değeri 0,867 ve genel ortalama değeri ise $\mathrm{X}=3,88$ olarak belirlenmiştir. Ayrıca ölçeğin Barlett Testi sonucu ki kare değeri 1126,736 ve $\mathrm{p}$ anlamlılık değeri 0,000 olarak gerçekleşmiştir. Kaiser-Meyer-Olkin (KMO) örneklem değeri 0,866'dır. Elde edilen değerler, veri setinin faktör analizi için uygun olduğunu işaret etmektedir.

İlk faktörün (Kariyer Algisl) toplam varyansı açıklama oranı \% 52,284 düzeyindedir ve beş madde ile ifade edilmektedir. Bu faktörün öz değeri 4,706'dır. Kariyer algısı faktörü güvenilirlik değeri 0,849 'dur ve $\mathrm{p}=0,000$ düzeyinde anlamlıdır. $\mathrm{Bu}$ faktöre, katılımcılar ortalama değer olarak $\mathrm{X}=3,82$ vermişlerdir. İkinci faktörün (Kariyer
Değişimi) toplam varyansı açıklama oranı \% 11,317 düzeyindedir ve dört madde ile ifade edilmektedir. $\mathrm{Bu}$ faktörün öz değeri 1,019'dur. Kariyer değişimi faktörü güvenilirlik değeri 0,721 'dir ve $\mathrm{p}=0,000$ düzeyinde anlamlıdır. $\mathrm{Bu}$ faktöre, katılımcılar ortalama değer olarak $X=3,99$ vermişlerdir. Katılımcılar en yüksek ortalama değer olarak "Mutfakta bilgi teknolojileri açısından donaniml olmam, gelecekteki hedeflerime katkl verecektir", "Gelecekte mutfakta alanımla ilgili teknik bilgiye ileri düzeyde sahip olmak istiyorum" $\mathrm{X}=4,14$ ile ifadelerine cevap vermiş̧lerdir. $\mathrm{Bu}$ durum hem $\mathrm{y}$ kuşağının mutfaklardaki teknolojiyi ve teknik gelişmeleri takip etmek konusunda oldukça önem verdiklerini göstermektedir. Ancak sektörün içinde fiilen çalışan y kuşağı mutfak çalışanları "Alanımda akademik kariyer planliyorum" ifadesine $\mathrm{X}=3,49$ gibi ortalama bir değer vererek, bu alanda kararsız oldukları yorumlanabilmektedir.

\section{BULGULAR}

\section{Katılımcıların Demografik ve Mesleki Özellikleri}

Araştırma bulgularında ilk olarak Tablo 3'de katılımciların demografik ve bazı mesleki özelliklerine göre veriler belirtilmektedir.

Tablo 3: Katılımcıların Demografik ve Mesleki Özelliklerine İlişsin Veriler

\section{Cinsiyet}

Erkek

Kadın

Yaş

20 Yaş ve Altı

21-25 Yaş

26-30 Yaş

31-39 Yaş

\section{Medeni Durum}

Evli

Bekar

\section{Eğitim Düzeyi}

İlköğretim

Lise

Ön Lisans

Lisans

Lisansüstü

$\begin{array}{cc}\text { Frekans } & \text { \% } \\ 188 & 75,2 \\ 62 & 24,8\end{array}$

46

18,4

97

38,8

42

16,8

65

26,0

73

29,2

177

70,8

20,0

36,0

$\begin{array}{ll}90 & 36,0 \\ 32 & 12,8\end{array}$

$78 \quad 31,2$ 


\section{Mesleği Nasıl Seçtiniz?}

Aile mesleği

$\begin{array}{cc}28 & 11,2 \\ 212 & 84,8 \\ 10 & 4,0\end{array}$

$\mathrm{Bu}$ mesleğe ilgi duyuyorum

4,0

Mecburiyetten seçtim

10 Yıl sonra kendinizi mesleğinizde nerede görmek istiyorsunuz?

Kendi işimi kurmayı planlıyorum.

36,8

Kurumsal özel bir işletmede çalışmayı planlıyorum.

$\begin{array}{ll}92 & 36,8 \\ 12 & 4,8\end{array}$

İyi bir işletmede üst düzey yönetici olmayı planlıyorum.

29,6

Yurtdışında mesleğimde iyi bir kariyer planlıyorum.

74

20,0

Gelecekte bu mesleği devam etmeyi düşünmüyorum.

50

8,8

\section{Mesleğinizde kariyer hedefleriniz var mı?}

Evet

$214 \quad 85,6$

Hayır

$18 \quad 7,2$

Kararsizim

$18 \quad 7,2$

Mesleğinizde tecrübeniz?

3 Y1l ve alt1

$\begin{array}{cc}114 & 45,6 \\ 40 & 16,0 \\ 34 & 13,6 \\ 62 & 24,8 \\ \mathbf{2 5 0} & \mathbf{1 0 0}\end{array}$

4-7 y1l

100

Araştırmada katılımcıların \%75,2'sini erkekler oluştururken, \%55,6'sını 21-30 yaş grubu oluşturmaktadır. Katılımcıların \%68,4'ü bekar ve \%56's1 ilköğretim ve lise mezunlarından oluşmaktadır. Ayrıca katılımcıların \%84,8'i bu mesleğe ilgi duydukları için tercih ettiklerini belirtirlerken, \%36,8'i 10 y1l sonra kendilerini kendi kuracakları işlerinin başında görmeyi ve \%29,6's1 iyi bir işletmede üst düzey bir yönetici olmayı planlamaktadırlar. Katılımcıların \%85,6's1 mesleklerinde kariyer hedeflerinin olduğunu

belirtirlerken, \%45,6'sının daha henüz mesleki tecrübeleri 3 yıl ve altında olduğunu belirtmişlerdir.

Değişkenler Arası Farklııkların Belirlenmesi TTesti

T testi iki örneklem grubu arasında ortalamalar açısından fark olup olmadığını araştırmak için kullanılır. T testi, bir gruptaki ortalamanın diğer gruptaki ortalamadan önemli derecede farklı olup olmadığını belirler (Kalaycı, 2008).

Tablo 4: Faktör Boyutlarının T Testi Sonuçları

\begin{tabular}{|c|c|c|c|c|c|c|}
\hline Faktörler & Cinsiyet & Sayı (N) & A.O. & S.S. & t-Değeri & p-Değeri \\
\hline \multirow[t]{2}{*}{ Kariyer Alg1s1 } & Erkek & 188 & 3,78 & ,992 & \multirow[t]{2}{*}{$-1,261$} & \multirow[t]{2}{*}{,208 } \\
\hline & Kadın & 62 & 3,95 &, 571 & & \\
\hline \multirow[t]{2}{*}{ Kariyer Değişimi } & Erkek & 188 & 3,98 & ,815 & \multirow[t]{2}{*}{$-1,738$} & \multirow[t]{2}{*}{,085 } \\
\hline & Kadın & 62 & 4,16 & ,666 & & \\
\hline \multirow[t]{2}{*}{ Kariyer Alg1s1 } & Evli & 177 & 3,74 & ,901 & \multirow[t]{2}{*}{2,174} & \multirow[t]{2}{*}{,031 } \\
\hline & Bekar & 73 & 4,02 & ,902 & & \\
\hline \multirow[t]{2}{*}{ Kariyer Değişimi } & Evli & 177 & 4,00 & ,833 & \multirow[t]{2}{*}{,- 855} & \multirow[t]{2}{*}{,394 } \\
\hline & Bekar & 73 & 4,08 & 649 & & \\
\hline
\end{tabular}


Tablo 4'de katılımcıların cinsiyetlerine göre kariyer algıları ve kariyer değişimleri arasında (p>.05) anlamlılık düzeyinde bir farklıl1k bulunmamıştır. Medeni durumlarına göre, kariyer algiları ile $(\mathrm{p}<.05)$ arasinda anlamlılık düzeyinde bir farklılık belirlenmiştir. Katılımcılardan bekarlar $(x=4,02)$, evlilere göre $(x=3,74)$ daha fazla kariyer alg1s1 konusunda hedefleri olduğu belirlenmiştir. Ancak medeni durumlarına göre, kariyer değişimleri arasında ( $>$ >.05) anlamlılık düzeyinde her hangi bir farklılık belirlenmemiştir.

\section{Tek Yönlï Varyans Analizi}

İkiden fazla bağımsız grubun ortalamalarının birbirinden farklı olup olmadığını test etmek amacıyla kullanılan istatistiksel analiz yöntemine tek yönlü varyans analizi denir (Sipahi, Yurtkoru ve Çinko, 2008). Tek yönlü varyans analizinin ön şartı grup varyanslarının homojen olmasıdır. Tablo 5'de kariyer algısı bağımlı değişkeni için Levene testi sonuçlarına göre grup varyansları homojen değildir $(\mathrm{p}<0,05)$. Ancak kariyer alg1sı bağımlı değişkeninin $F$ değeri 1,167 ve $p$ değerinin ise $0,323>0,05$ olduğu belirlenmiştir. Buna göre kariyer algıları ile yaş grupları arasında anlamlı bir farklılık bulunamamıştır.

Kariyer değişimi bağımlı değişkeni için Levene testi sonuçlarına göre grup varyansları homojendir (p değeri 0,222>0,05). Bu durumda Tablo 5'de kariyer değişimi bağımlı değişkeninin $F$ değerinin 4,569 buna karş1l1k $p$ değerinin ise $0,004<0,05$ olduğu belirtilmektedir. Katılımcıların kariyer değişimleri ile yaş grupları arasında anlamlı bir farklılık olduğu belirlenmiştir. Araştırmada bulgularında dört grupta her bir grubun gözlem sayısı farklı olduğundan ikili karşılaştırma Tukey HSD Post-Hoc testi yorumlanmıştır.

Tablo 5: Yaş Grupları Değişkenine Göre Tek Yönlü Varyans Analizi Bulguları (n=250)

\begin{tabular}{|c|c|c|c|c|c|c|}
\hline \multicolumn{2}{|c|}{ Faktör Boyutları } & Karelerin & Serbestlik & Ortalamalar & $\mathbf{F}$ & Sig. \\
\hline \multirow{3}{*}{$\begin{array}{l}\text { Kariyer } \\
\text { Algisı }\end{array}$} & Gruplar arası & 2,884 & 3 & 0,961 & \multirow{3}{*}{1,167} & \multirow{3}{*}{0,323} \\
\hline & Grup İçi & 202,669 & 246 & 0,824 & & \\
\hline & Toplam & 205,553 & 249 & & & \\
\hline \multirow{3}{*}{$\begin{array}{l}\text { Kariyer } \\
\text { Değişimi }\end{array}$} & Gruplar aras1 & 8,072 & 3 & 2,691 & \multirow{3}{*}{4,569} & \multirow{3}{*}{ 0,004 } \\
\hline & Grup İçi & 144,884 & 246 & 0,589 & & \\
\hline & Toplam & 152,956 & 249 & & & \\
\hline
\end{tabular}

Tablo 6'da Tukey HSD Post-Hoc testi sonuçlarına göre kariyer değişimi bağımlı değişkeni ile yaş grupları arasındaki anlamlı farkın 31-39 yaş grupları 21-25 yaş grubu ve 26-30 yaş grupları arasında olduğu $(\mathrm{p}<0,05)$ görülmektedir. Buna göre 31-39 yaş grubu ( $\mathrm{x}=3,73), 21-25$ yaş grubuna göre $(x=3,83)$ ve 26-30 yaş grubuna göre daha düşük bir kariyer değişimi eğilimi sergilemektedirler. Bu durum 20'li yaşlardaki genç katılımcıların aşçılık mesleğinde kendi kişisel gelişimlerini sağlayarak kariyer değişimi eğilimlerinin daha fazla olduğunu göstermektedir.

Tablo 6: Yaş Gruplarına Göre Post Hoc Testi Bulguları $(n=250)$

\begin{tabular}{|l|l|l|l|l|l|}
\hline Kariyer Değişimi & Yaş Grupları & $\mathbf{n}$ & Ortalama & Ortalama Farkı (I-J) & p-değeri \\
\hline \multirow{3}{*}{ 20 ve altı (n=46) } & $21-25$ & 97 & 3,83 &,- 17784 &, 567 \\
\cline { 2 - 6 } & $26-30$ & 42 & 4,04 &,- 14286 &, 819 \\
\cline { 2 - 6 } & $31-39$ & 65 & 3,73 &,- 25769 &, 304 \\
\hline \multirow{3}{*}{$21-25$ Yaş (n=97) } & 20 ve altı & 46 & 3,74 &, 17784 &, 567 \\
\cline { 2 - 6 } & $26-30$ & 42 & 4,04 &, 03498 &, 995 \\
\cline { 2 - 6 } & $31-39$ & 65 & 3,73 &, $43553^{*}$ &, $\mathbf{0 0 3}$ \\
\hline \multirow{3}{*}{ 26-30 Yaş (n=42) } & 20 ve altı & 46 & 3,74 &, 14286 &, 819 \\
\cline { 2 - 6 } & $21-25$ & 97 & 3,83 &,- 03498 &, $\mathbf{0 4 4}$ \\
\cline { 2 - 6 } & $31-39$ & 65 & 3,73 &, $40055^{*}$ & \\
\hline
\end{tabular}




\begin{tabular}{|l|l|l|l|l|l|}
\hline \multirow{3}{*}{$31-39$ Yaş $(\mathrm{n}=65)$} & 20 ve alt1 & 46 & 3,74 &,- 25769 &, 304 \\
\cline { 2 - 6 } & $21-25$ & 97 & 3,83 &,- 43553 & $\mathbf{, 0 0 3}$ \\
\cline { 2 - 6 } & $26-30$ & 42 & 4,04 &,- 40055 & $\mathbf{, 0 4 4}$ \\
\hline
\end{tabular}

Tablo 7: Eğitim Değişkenine Göre Tek Yönlü Varyans Analizi Bulguları (n=250)

\begin{tabular}{|c|c|c|c|c|c|c|}
\hline \multicolumn{2}{|c|}{ Faktör Boyutları } & \multirow{2}{*}{$\begin{array}{l}\text { Karelerin } \\
\text { Ortalaması }\end{array}$} & \multirow{2}{*}{$\begin{array}{l}\begin{array}{l}\text { Serbestlik } \\
\text { Derecesi }\end{array} \\
3\end{array}$} & \multirow{2}{*}{$\begin{array}{l}\begin{array}{l}\text { Ortalamalar } \\
\text { Karesi }\end{array} \\
1,342\end{array}$} & $\mathbf{F}$ & Sig. \\
\hline \multirow{3}{*}{$\begin{array}{l}\text { Kariyer } \\
\text { Algisı }\end{array}$} & Gruplar arası & & & & \multirow{3}{*}{$\begin{array}{l}1,63 \\
8\end{array}$} & \multirow{3}{*}{$\begin{array}{l}0,18 \\
1\end{array}$} \\
\hline & Grup İçi & 201,526 & 246 & 0,819 & & \\
\hline & Toplam & 205,553 & 249 & & & \\
\hline \multirow{3}{*}{$\begin{array}{l}\text { Kariyer } \\
\text { Değişimi }\end{array}$} & Gruplar arası & 1,374 & 3 & 0,458 & \multirow{3}{*}{$\begin{array}{l}0,74 \\
3\end{array}$} & \multirow{3}{*}{$\begin{array}{l}0,52 \\
7\end{array}$} \\
\hline & Grup İçi & 151,582 & 246 & 0,616 & & \\
\hline & Toplam & 152,956 & 249 & & & \\
\hline
\end{tabular}

Tablo 7'de kariyer algısı bağımlı değişkeni için Levene testi sonuçlarına göre grup varyansları homojendir ( $\mathrm{p}$ değeri $0,051>0,05$ ). Ancak kariyer algısı bağımlı değişkeninin $F$ değeri 1,638 ve $p$ de ğerinin ise $0,181>0,05$ olduğu belirlenmiştir. Buna göre kariyer algıları ile eğitim seviyeleri arasında anlamlı bir farklılık bulunamamıştır. Kariyer değişimi bağımlı değişkeni için Levene testi sonuçlarına göre grup varyansları homojen değildir ( $p$ değeri $0,013<0,05$ ). Ayrıca kariyer değişimi bağımlı değişkeninin $F$ değeri 0,743 ve $p$ değerinin ise $0,527>0,05$ olduğu belirlenmiştir. $\mathrm{Bu}$ durumda katılımcıların kariyer değişimi ile eğitim seviyeleri arasında anlamlı bir farkl1lık bulunamamıştır.

Tablo 8: Tecrübe Değişkenine Göre Tek Yönlü Varyans Analizi Bulguları $(n=250)$

\begin{tabular}{|c|c|c|c|c|c|c|}
\hline \multicolumn{2}{|c|}{ Faktör Boyutları } & $\begin{array}{l}\text { Karelerin } \\
\text { Ortalaması }\end{array}$ & $\begin{array}{l}\text { Serbestlik } \\
\text { Derecesi }\end{array}$ & $\begin{array}{l}\text { Ortalamalar } \\
\text { Karesi }\end{array}$ & $\mathbf{F}$ & Sig. \\
\hline \multirow{3}{*}{$\begin{array}{l}\text { Kariyer } \\
\text { Algısı }\end{array}$} & Gruplar arası & 8,007 & 3 & 2,669 & \multirow{3}{*}{3,324} & \multirow{3}{*}{$0,020^{*}$} \\
\hline & Grup İçi & 197,546 & 246 & 0,803 & & \\
\hline & Toplam & 205,553 & 249 & & & \\
\hline \multirow{3}{*}{$\begin{array}{l}\text { Kariyer } \\
\text { Değişimi }\end{array}$} & Gruplar arası & 6,565 & 3 & 2,188 & \multirow{3}{*}{3,677} & \multirow{3}{*}{$0,013^{*}$} \\
\hline & Grup İçi & 146,391 & 246 & 0,595 & & \\
\hline & Toplam & 152,956 & 249 & & & \\
\hline
\end{tabular}

Tablo 8'de kariyer algısı bağımlı değişkeni için Levene testi sonuçlarına göre grup varyansları homojen değildir $(\mathrm{p}<0,05)$. Kariyer algısı bağımlı değişkeninin $F$ değerinin 3,324 buna karşıllk $p$ değerinin ise $0,020<0,05$ olduğu belirtilmektedir. Katılımcıların kariyer algıları ile tecrübeleri arasında anlamlı bir farklılık olduğu belirlenmiş̧tir. Araştırmada bulgularında dört grupta her bir grubun gözlem sayısı farklı olduğundan ikili karş1laştırma Tukey HSD Post-Hoc testi yorumlanmıştır. Tablo 8'de ayrıca kariyer değişimi bağımlı değişkeni için Levene testi sonuçlarına göre grup varyansları homojen değildir $(\mathrm{p}<0,05)$. Kariyer değişimi bağımlı değişkeninin $F$ değerinin 3,677 buna karş1l1k $p$ değerinin ise $0,013<0,05$ olduğu belirtilmektedir. Katılımcıların kariyer değişimi eğilimleri ile tecrübeleri arasında anlamlı bir farklılık olduğu belirlenmiştir. 
Tablo 9: Tecrübe Değişkenine Göre Post Hoc Testi Bulguları $(n=250)$

\begin{tabular}{|c|c|c|c|c|c|}
\hline Kariyer Algısı & Yaș Grupları & $\mathbf{n}$ & Ortalama & Ortalama Farkı (I-J) & p-değeri \\
\hline \multirow{3}{*}{3 ve alt $1(n=114)$} & 4-7 Y11 & 40 & 3,98 &,- 18325 & ,682 \\
\hline & 8-11 Y11 & 34 & 3,43 & ,36646 & , 158 \\
\hline & 12 ve üstü & 62 & 3,99 &,- 19179 &, 528 \\
\hline \multirow{3}{*}{ 4-7 Yil $(\mathrm{n}=40)$} & 3 ve alt1 & 114 & 3,80 & , 18325 & ,682 \\
\hline & 8-11 Y1l & 34 & 3,43 &, $54971^{*}$ & ,045 \\
\hline & 12 ve üstü & 62 & 3,99 &,- 00855 & 1,000 \\
\hline \multirow{3}{*}{$8-11 Y_{11}(n=34)$} & 3 ve alt1 & 114 & 3,80 &,- 36646 & , 158 \\
\hline & 4-7 Y11 & 40 & 3,98 &,$- 54971^{*}$ & ,045 \\
\hline & 12 ve üstü & 62 & 3,99 &,$- 55825^{*}$ & ,020 \\
\hline \multirow{3}{*}{12 ve üstü $(n=62)$} & 3 ve alt1 & 114 & 3,98 & ,19179 &, 528 \\
\hline & 4-7 Y11 & 40 & 3,43 & 00855 & 1,000 \\
\hline & 8-11 Yil & 34 & 3,43 &,$- 55825^{*}$ & ,020 \\
\hline Kariyer Değişimi & Yaş Grupları & $\mathbf{n}$ & Ortalama & Ortalama Farkı (I-J) & p-değeri \\
\hline \multirow{3}{*}{3 ve alt $(n=114)$} & 4-7 Y11 & 40 & 4,05 & ,08158 & ,939 \\
\hline & $8-11 Y_{11}$ & 34 & 3,63 &, $49923^{*}$ & ,006 \\
\hline & 12 ve üstü & 62 & 4,03 & ,09932 & ,847 \\
\hline \multirow{3}{*}{ 4-7 Yil $(n=40)$} & 3 ve alt1 & 114 & 4,13 &,- 08158 & ,939 \\
\hline & 8-11 Yil & 34 & 3,63 & ,41765 & ,096 \\
\hline & 12 ve üstü & 62 & 4,03 & 01774 & 999 \\
\hline \multirow{3}{*}{$8-11 Y_{11}(n=34)$} & 3 ve alt1 & 114 & 4,13 &,$- 49923^{*}$ & ,006 \\
\hline & 4-7 Y11 & 40 & 4,05 &,- 41765 & ,096 \\
\hline & 12 ve üstü & 62 & 4,03 &,- 39991 & ,074 \\
\hline \multirow{3}{*}{12 ve üstü $(n=62)$} & 3 ve alt1 & 114 & 4,13 &,- 09932 & ,847 \\
\hline & 4-7 Y11 & 40 & 4,05 &,- 01774 & ,999 \\
\hline & 8-11 Yil & 34 & 3,63 & ,39991 & 074 \\
\hline
\end{tabular}

Tablo 9'da Tukey HSD Post-Hoc testi sonuçlarına göre kariyer algısı bağımlı değişkeni ile tecrübe yılları arasındaki anlamlı farklılığın 8-11 yıl tecrübeye sahip katılımcıların, 4-7 y1l ile 12 yıl ve üstü tecrübeye sahip katılımcılar arasında olduğu $(p<0,05)$ görülmektedir. Buna göre 8-11 y1l tecrübeye sahip katılımcılar $(x=3,43), 4-7$ y1l tecrübeye sahip olanlara göre $(x=3,98)$ ve 12 yıl ve üstü $(x=3,99)$ tecrübeye sahip olanlara göre daha düşük bir kariyer algısı eğilimindedirler. Ayrıca kariyer değişimi bağımlı değişkeni ile tecrübe yılları arasında anlamlı farklılığın 3 y1l ve altında $(x=4,13)$ tecrübeye sahip katılimcilar, 8-11 y1 $(x=3,63)$ tecrübeye sahip katılımcılara göre daha fazla kariyer değişimi eğilimindedirler. Bu durum aşçl1ı mesleğine yeni giren grubun kariyer değişimi ve gelecekte mesleki gelişimi konusunda daha fazla beklenti ve hedefleri olduğunu göstermektedir.

\section{SONUÇ VE TARTIŞMA}

Günümüzde televizyonlarda yayınlanan yemek programlarında ünlü şeflerin yer alması ve aşçılık mesleğinin ününün artması genç kuşağı, mutfak departmanlarında çalışmaya özendirmiş (Pratten, 2003a; Pratten, 2003b) ve mutfaklarda y kuşağ çalışanları yerini almaya başlamıştır. Bu y kuşağı mutfak çalışanlarının kariyer planları ve beklentilerinin ortaya konmasi hem mutfak çalışanlarının hem de işletmelerin başarısında önemli rol oynamaktadır. Bundan dolayı y kuşağı çalışanlarının kariyer planlamaları ve beklentilerinin belirlenmesi çalışmanın temel 
amacını oluşturmaktadır. Araştırma kapsamında kolayda örneklem yöntemi ile İstanbul ilinde 8 adet beş yıldızlı otelde 250 y kuşağı mutfak çalışanından anket yöntemi ile veriler toplanmıştır. Alanyazında turizm ve otelcilik sektörü içerisinde kariyer planlaması ile ilgili çalışmaların sayısı artış göstermesine rağmen (Kurnaz ve diğerleri; 2014 Ahmetoğulları ve Güneş, 2017; Işık ve diğerleri; 2018; Önesen ve Topaloğlu, 2018; Özdemir ve Önçel; 2019; Eren, 2019) y kuşağ1 mutfak çalışanlarının kariyer planlamasını araştıran bir çalışmaya rastlanılmamıştır. Bu nedenle araştırma kapsamında elde edilen bulgular teoriye katk1 sağlamaktadır.

Araştırma sonuçlarına göre kariyer algısına yönelik gerçekleştirilen açımlayıcı faktör analizinde en yüksek ortalama değerin "Mutfakta bilgi teknolojileri açısından donanımlı olmam, gelecekteki hedeflerime katk1 verecektir", "Gelecekte mutfakta alanımla ilgili teknik bilgiye ileri düzeyde sahip olmak istiyorum" $(X=4,14)$ ifadeleri almıştır. Bu durum Brown (2013)'de ifade ettiği gibi Y kuşağının teknolojik yeniliklerin takibine ve kariyer gelişimlerine önem verdiğini göstermektedir.

Y kuşağı mutfak çalışanlarının cinsiyetlerine göre kariyer algıları ve kariyer değişimleri arasında $(\mathrm{P}>$.05) bir farklılık bulunamamıştır. Fakat ilgili alanyazın incelendiğinde cinsiyet değişkeni ile kariyer algısı arasında anlamlı farklılıklar olduğu görülmektedir (Akdemir ve diğerleri, 2013; Ahmetoğulları ve Güneş, 2017) . Yine kariyer değişimi ile cinsiyet değişkeni arasında da anlamlı farklılık olduğu belirlenmiştir (Ahmetoğulları ve Güneş, 2017) . Bu nedenle araştırma sonucu alanyazınla farklılık göstermektedir. Diğer bir yandan medeni duruma göre kariyer algısı farklılık göstermektedir. Y kuşağı mutfak çalışanlarından bekâr olanlar $(x=4,02)$, evlilere göre $(x=3,74)$ daha fazla kariyer hedeflerine sahip olduğu sonucuna ulaşılmıştır. Bu durum bekâr mutfak çalışanlarının aile sorumlulukları olmadığı ve kariyer planlamalarında kendi başına daha özgür karar almalarına bağlanabilir. Fakat evli kadın aşçılar annelik görevi ve aile sorumluklarından dolayı kariyer planlamalarında zorluk yaşamaktadırlar (Haddaji ve diğerleri, 2017). Kariyer değişiminin ise y kuşağı mutfak çalışanlarının medeni durumlarına göre değişmediği belirlenmiştir.
Y kuşağı mutfak çalışanlarının kariyer algılarının, yaşlarına göre değişim göstermediği tespit edilmiştir $\mathrm{Bu}$ kapsamda y kuşağı içinde farklı yaşlarda olan mutfak çalışanlarının kariyer algıları benzerlik göstermektedir. Bu sonuç Büyükyılmaz, Ercan ve Gökerik (2016)'nın çalışma sonucunu desteklemektedir. Fakat Ahmetoğulları ve Güneş (2017) ve Akdemir ve diğerleri (2013)'nin bulgularından farklılık göstermektedir. Ayrıca mutfak çalışanlarının kariyer değişimleri ile yaş grupları arasında ise anlamlı bir farklılık olduğu belirlenmiştir. Y kuşağı çalışanlarının kariyer değişikliğini sik olarak gerçekleştirmeleri göz önüne alınırsa (Acıoğlu,2015) bu sonuç alanyazını desteklemektedir.

Araştırmanın bir diğer sonucu da y kuşağı mutfak çalışanlarının kariyer algıları ve kariyer değişimlerinin sahip olduğu eğitim durumuna göre değişmemektedir. Bu sonuç Akdemir ve diğerleri (2013)'nin araştırma sonucu ile paralellik göstermektedir. Son olarakta y kuşağı mutfak çalışanlarının kariyer algıları ve değişimleri ile iş tecrübelerine göre farklılık gösterdiği belirlenmiştir. Özelikle mutfak alanında az iş tecrübesine sahip olan y kuşağı aşçıları daha fazla kariyer değişikliği gerçekleştirmektedir.Mutfak alanında yeni işe başlamış personele mesleği sevdirmek ve kariyer değişiminin önüne geçmek için deneyimli personellere önemli görevler düşmektedir. Tecrübeli personeller, y kuşağ1 çalışanları ile sorumluluklarını paylaşarak, onların iş yerinde kendini önemli hissetmelerini sağlamalıdır. Ayrıca y kuşağı çalışanlarına mentörlük yaparak onların kariyer planlamalarına yardımcı olabilirler ve onlara çalıştıkları iş yerinin bir parçası olduğunu hissettirmek için piknikler, akşam yemekleri ve çeşitli spor etkinlikleri düzenleyebilirler (Gursoy ve diğerleri, 2008).

$\mathrm{Bu}$ çalışmanın bazı sınırlılıkları bulunmaktadır. Bu çalışma İstanbul'da 8 tane beş yıldızlı otelin y kuşağı mutfak çalışanın görüşleri ile sınırlıdır. Bundan sonraki çalışmalar için İstanbul'da daha fazla beş yıldızlı otel dâhil edilerek örneklem genişletilebilir. Ayrıca farklı şehirlerde ve x kuşağı aşçılar ile de araştırmalar gerçekleştirilebilir ve bunun sonucunda y kuşağı ile x kuşağı aşçılarının kariyer planlamaları ve beklentileri arasındaki benzerlikler / farkl1liklar ortaya konabili 


\section{KAYNAKÇA}

Acar, R. ve Özdaşl1, K .( 2017). Bireysel kariyer planlama yapmanın öğrenci başarısı üzerinde etkisi: SBMYO öğrenci üzerine bir araştırma. Mehmet Akif Üniversitesi Sosyal Bilimler Enstitüsü Dergisi, 9 (21), 302- 314.

Akdemir, A., Konakay, G., Demirkaya, H., Noyan, A., Demir, B., A ̆g, C., Pehlivan, Ç., Özdemir, E., Akduman, G., Eregez, H., Öztürk, İ. ve Balc1, O. (2013). Y kuşağının kariyer algısı, kariyer değişimi ve liderlik tarzı beklentilerinin araştırılması. Ekonomi ve Yönetim Araştırmaları Dergisi, 2(2), 1142-1554.

Altuntuğ, N.(2012). Kuşaktan kuşağa tüketim olgusu ve geleceğin tüketici profili. Organizasyon ve Yönetim Bilimleri Dergisi, 4(1), 203-212.

Acılıŏlu, İ.(2015). İş'te Y Kuşă̆ı. Elma Yayınevi: Ankara.

Ahmetoğulları, K. ve Güneş, M. (2017). MYO öğrencilerinin kariyer planlamasi: Hilvan örneği. International Journal of Academic Value Studies, 3 (13), 166-177.

Akdemir, A., Karagöz, A., Salihoğlu, G., Konakay, G., Adalı, P., Koçyiğit, E., Zaimoğlu, Ö. (2015). Meslek yüksekokulu öğrencilerinin kariyer planlarının motivasyon düzeylerine etkilerinin araştırılması. Ekonomi ve Yönetim Araştırmalar Dergisi, 4 (1), 53-90.

Akgemci, T. ve Kalfaoğlu, S.(2018). X ve y kuşakların kariyer uyum yetenek düzeylerini belirlemeye yönelik bir araştırma: Lise öğretmenleri örneği. Nevşsehir Hacı Bektaş Veli Universitesi SBE Dergisi, 8 (2), 231-247.

Bekmezci, M.(2017). Nesillerin karşılaştırılması ve iş dünyasında ' $\mathrm{Y}$ ' kuşağına kuramsal bir bakış. Toros Üniversitesi IIISBF Sosyal Bilimler Dergisi, 4(7), 101-111.

Büyükyılmaz, O., Ercan, S. ve Gökerik, M. (2016). Öğrencilerin kariyer planlama tutumlarının demografik faktörler açısından değerlendirilmesi: Karabük üniversitesi işletme fakültesi öğrencileri üzerine bir araştırma, Insan ve Toplum Bilimleri Araştırmalar Dergisi, (7), 2065-2076.

Brown, M.(2013). Y kuşağı inovasyon araştırması, http://www.deloitteegitimvakfi.org.

tr/UserFiles/Documents/Y_Kusagi_Inovasyon.pdf, Erişim Tarihi: 20.06.2019.
Can, H., Kavuncubaşı, Ş. ve Yıldırım, S. (2009).

Kamu ve Özel Kesimde İnsan Kaynaklarl Yönetimi. Ankara: Siyasal Yayınevi.

Çavuş, Ş. ve Kaya, A.(2015). Turizm Lisans Eğitimi Alan Öğrencilerin Kariyer Planları ve Turizm Sektörüne Yönelik Tutumu. Manas Sosyal Araştırmalar Dergisi.4(5):102-117.

Çiftçi B. (2011). Kariyer Planlama. (Ed.Ugur Dolgun). İnsan

Kaynakları Yönetimi: Bursa: Ekin Basın Yayın Dağıtım

Dessler, G. (2013). Human Resource Management. Thirteenth Edition. USA: Prentice Hall.

Deloitte (2017). Y kuşağının artık sadece beklentileri değil, kaygıları da yüksek, https://www2.deloitte.com/tr/tr/pages/aboutdeloitte/articles/deloitte-y-kusagi-arastirmasi2017.html, Erişim Tarihi: 25.06.2019.

Eren, R.(2019). Yiyecek ve içecek müdürlerinin kariyer basamaklar1. Journal of Tourism and Gastronomy Studies, 7(1), 169-184.

Ergün, Ö, D.(2013). Insan Kaynakları Yönetimi. T.C. Anadolu Üniversitesi Yayını: Eskişehir.

Ertürk, M. (2011). İnsan Kaynaklarl Yönetimi. İstanbul: Beta Yayınevi.

Fox, A. (2011). Mixing it up, https://www.shrm. org/hr-today/news/hr-magazine/

pages/0511fox.aspx, Erişim Tarihi:13.07.2019.

Göktaş, P.(2017). Kuşakların kariyer yaklaşımları ile ilişkilendirilmesine yönelik bir çalışma. Kafkas Üniversitesi İktisadi ve İdari Bilimler Fakültesi ( KAÜIİBFD), 8(6), 373-393.

Güzel, T., Akdağ, G., Güler, O. ve Şener, S. (2014). Turizm Eğitimi Alan Öğrencilerin Turizmde Kariyer Algılamaları: Çanakkale, Mersin ve Kıbrıs'ta Bir Araştırma. 3.Doğu Akdeniz Sempozyumu Bildiriler Kitab1, 18 Nisan 2014, Mersin, s.176-187.

Gursoy, D., Maier, T.A. ve Chi, C.G.(2008). Generational differences: An examination of work values and generational gaps in the hospitality workfoce. International Journal of Hospitality Management, 27, 448-458.

Harbalığlu, Ü. ve Ünal, İ.(2014). Aşçılık programı öğrencilerinin mesleki tutumlarının belirlenmesi: Ön lisans düzeyinde bir uygulama. Turizm Akademik Dergisi, 1(1),57-67. 
Haddaji, M., Albors-Garrigos, J. ve GarciaSegovia, P.(2017). Women chefs experience: kitchen barriers and success factors. Internatinonal Journal of Gastronomy and Food Science, 9, 4954.

Hair J. F., Black, W., Babin, J., Anderson, R. E. ve Tatham, R. L. (2006). Multivariate Data Analysis. Altıncı Baskı. New Jersey: Prentice Hall.

Işık, N., Pektaş, Ç. ve Atılgan, E. (2018). Turizm ön lisans eğitiminde kariyer planlaması: Gaziantep örneği. Türk Turizm Araştırmaları Dergisi, 2 (2), $10-20$.

İstanbul Kültür ve Turizm Müdürlüğü (2018). İstatistikler, Turizm Belgeli Tesisler, https://istanbul.ktb.gov.tr/TR-172646/turizmbelgeli-tesisler.html, Erişim Tarihi. 20.06.2019.

Kalayc1, Ş. (2008). SPSS Uygulamaları Çok Değişkenli İstatistik Teknikleri. Ankara: Asil Yayın.

Karasar, N. (2014). Bilimsel Araştırma Yöntemi. Ankara: Nobel Yayın Dağıtım.

Kozak, M. A. ve Kızılırmak, İ. (2001). Türkiye'de Meslek Yüksekokulu Turizm Otelcilik Programı Öğrencilerinin Turizm Sektörüne Yönelik Tutumlarının Demografik Değişkenlere Göre Değişimi: Anadolu, Akdeniz ve Karadeniz Teknik Üniversitesi Öğrencileri Üzerine Bir Uygulama. Anotolia: Turizm Araştırmaları Dergisi, 12: 9-16. Kozak, M. A. ve Kızılırmak, İ. (2001). Türkiye'de Meslek Yüksekokulu Turizm Otelcilik Programı Öğrencilerinin Turizm Sektörüne Yönelik Tutumlarının Demografik Değişkenlere Göre Değişimi: Anadolu, Akdeniz ve Karadeniz Teknik Üniversitesi Öğrencileri Üzerine Bir Uygulama. Anotolia: Turizm Araştırmaları Dergisi, 12: 9-16.

Koç, M., Öztürk, L. ve Yıldırım, A. (2016). An empirical study on the generation $\mathrm{X}$ and $\mathrm{Y}$ for determining organizational commitment differences. Global Business Research Congress, 2, 69-78.

Konakay, G. (2018). Y kuşağı değerlerinin kariyer tercihleri açısından incelemesi. Journal of Entrepreneurship and Development, 13(1), 79-92.

Kocabey, U. (2010). İsletmelerde performans değerlendirme, geri bildirim, kariyer planlama ve örgütsel bağlılık arasındaki ilişkilere yönelik bir araştırma (Yayımlanmamış Yüksek Lisans Tezi), Gebze İleri Teknoloji Enstitüsü, Sosyal Bilimler Enstitüsü, Gebze.
Kurnaz, A., Kurnaz, H.A. ve Kılıç, B. (2014). Ön lisans düzeyinde eğitim alan aşçlık programı öğrencilerinin mesleki tutumlarının belirlenmesi. Muğla Sitkı Koçman Üniversitesi Sosyal Bilimler Enstitüsü Dergisi, 32, 41-61.

Manzoori- Stamford, J.(2013). Loving Life in Hospitality, https://www.thecaterer.com/ articles/345455/loving-life-in-hospitality-andrewscott-host-contract-management, Erişim Tarihi: 15.06.2019.

Metin, S. ve Kizıldağ, D. (2017). X ve Y kuşaklarının kariyer beklentilerinin farklılaşması: Otomotiv sektöründe bir araştırma. Mustafa Kemal Üniversitesi Sosyal Bilimler Enstitüsü Dergisi,40, 340-363.

Önesen, F. ve Topaloğlu, C. (2018). Otel çalışanlarının mesleki ve gelecek beklentilerine yönelik bir araştırma: Antalya örneği. Journal of Tourism and Gastronomy Studies, 6(3), 40-59.

Özdemir, N. ve Önçel, S.(2019). Gastronomi ve mutfak sanatları bölümü lisans öğrencilerinin sektöre yönelik algılarının kariyer yapma niyetlerine etkisi. Journal of Tourism and Gastronomy Studies, 7(2), 1159-1176.

Öztemel, K.(2019). Kariyer Planlama ve Geliştirme. Ankara: Pegem Akademi.

Öztürk, Y. ve Görkem, O.( 2012). Aşçılık eğitimi yeterliliğini etkileyen faktörlerin değerlendirilmesine yönelik bir araştırma. Ticaret ve Turizm Eğitim Fakültesi Dergisi, 2, 113-129.

Perçin, N.Ş. ve Çetin, B.(2014). Kariyer Yönetimi. N.Ş.Perçin, Güzel, B, Tükeltürk, Ş. A(Ed.). İçinde Turizm İşletmelerinde Insan Kaynaklarl Yönetimi ve Uygulamalart (ss.165-181). İstanbul: Beta Yayınları.

Prattern, J. D. (2003a). The training and retention of chefs. International Journal of Contemporary Hospitality Management, 15(4), 237-242.

Prattern, J. D. (2003b). What makes a great chef. British Food Journal, 105 (7), 454-459.

Reeves, T. C. ve Oh, E. (2008). Generational Differences. İçinde: J.M. Spector, M.D. Merrill, J. Van Merrienboer, M. P.Driscoll (Ed.), In Handbook of Research on Educational Communications and Technology, New York: Taylor \& Francis Group, ss. 275-290.

Saxena, P. ve Jain R. (2012). Managing career aspirations of generation $\mathrm{Y}$ at work place. 
International Journal of Advanced Research in Computer Science and Software Engineering, 2 (7), $114-118$.

Sipahi, B., Yurtkoru, E. S. ve Çinko, M. (2008). Sosyal Bilimlerde SPSS'le Veri Analizi. İstanbul: Beta Yayınevi.

Sheahan, P.(2009). Generation Y: Thriving and surviving with generation $\mathrm{Y}$ at work, New York: Hardie Grant Books.

Tavşancıl, E. (2014). Tutumların Ölçülmesi ve SPSS ile Veri Analizi. Ankara: Nobel Yayınevi.

Taşlıyan, M., Arı, N. ve Duzman, B. (2011). İnsan kaynakları yönetiminde kariyer planlama ve kariyer yönetimi: İİBF öğrencileri üzerinde bir alan araştırmas1. Organizasyon ve Yönetim Bilimleri Dergisi, 3(2), 231-241.

Tekin, H. (2000). Eğitimde Ölçme ve Değerlendirme. Ankara: Yarg1 Yayınları.

Temeloğlu, E. ve Aksu, M .(2016). Turizm eğitimi alan öğrencilerin kişilik özeliklerinin turizmde kariyer yapma istekleri üzerinde etkisi: Çanakkale On sekiz Mart Üniversitesi Örneği. The Journal of International Social Research, 9 (43), 1513-1521.

Türk, E. T. (2013). Kuşak kuşak teknoloji ve sosyal hayat, http://isfam.org/kusak-kusakteknoloji-ve-sosyalhayat/, Erişim Tarihi: 13.07.2019.

Tyler, K. (2007). The Tethered Generation, https://www.shrm.org/hr-today/news/hr-

magazine/pages/0507cover.aspx, Erişim Tarihi: 13.07.2019.
Ural, A.ve Kılıç, İ. (2006). Bilimsel Araştırma Süreci ve SPSS ile Veri Analizi. Ankara: Detay Yayıncilık.

Ünsal, P.(2014). Kariyer Gelişim Kuramları ve Kariyer Danışmanlığı..Ankara: Nobel Yayıncılığı.

Yaprak, Ş., Hotamışlı, M., ve Gerek, M.(2010). Örgütsel kariyer yönetimi: Tekstil işletmelerinde bir uygulama. Süleyman Demirel Üniversitesi İktisadi ve İdari Bilimler Fakülte Dergisi, 15(1), 399-421.

Y1lmaz, G., Erdem, Ö. ve Arman, A.(2018). Şef adaylarının niteliklerine ilişkin mutfak şeflerinin görüssleri. Journal of Tourism and Gastronomy Studies, 6(3), 273-294.

Y1lmaz, Ö., Y1lmaz, Y. ve Y1lmaz, Ö.(2013). Yiyecek İçecek İşletmeciliği. Ankara: Detay Yayıncilik.

Zopiatis, A., Kyprianou, G., ve Pavlou, I.(2011). Occupational challenges facing chefs: The case of Cyprus. Journal of Quality Assurance in Hospitality Tourism, 12 (2), 104-120.

Zvikaite-Rotting, O. (2007). Generation Gap: Resolving Conflicts Between

Generations,https://pdfs.semanticscholar.org/0bc8/ a6bf879ea4a108eced1b24c8203bf220856c.pdf, Erişim Tarihi:10.06.2019.

Wang, Y. F. ve Tsai, C. T. S. (2012). Analysis of career competency of food and beverage managers in international tourist hotels in Taiwan. International Journal of Hospitality Management, 31(2), 612-616. 